\title{
Christian Witness in a Marketplace of Cultured Alternatives.
}

\section{A. H. Mathias Zahniser}

\author{
Abstract In On Religion: Speeches to its Cultured Despisers (1799; Eng. Ed. 1958), Friedrich \\ Schleiermacher launched an apologetic for Christian faith at people who thought being rational \\ and well educated entailed rejecting the truth claims of religion. Today we encounter cultured \\ adherents of alternative religions just down the street from us. They believe their religion \\ represents the best way, if not the only true way, of truth and life. Four mottos capture an \\ appropriate way of Christian witness to such people: Building relationships is more important than \\ tearing down strongholds; You can never know enough, but you can easilty know too much; It is \\ better to inspire hope than to be admired; and Overcome yourself not the enemy. These mottos say \\ in essence, build relationships, keep persons in the foreground, let God work within them, and \\ overcome fear and false witness within yourself. This paper was originally published in \\ Missiology: An International Journal, 30/2 (April, 2003). It has been reprinted in Lo and Boyd
} 2006: $37-45$.

At the beginning of the 19th century Friedrich Schleiermacher published a book of lectures on religion directed to "its cultured despisers" ([1799] 1988). In it he launched an apologetic for Christian faith at people who thought being rational and well educated entailed rejecting the truth claims of Christianity. Although people who think maturity and education entail rejection of the gospel still exist, a very different kind of person challenges the Christian witness at the beginning of the 21 st century.

Today we want to know how to share the gospel with cultured adherents of alternative religions just down the street from us. In other words, pluralism has reached our neighborhoods. Believe me, these neighbors do not believe in ideological pluralism - although plenty of that exists around us too. Often these people believe their religion represents the best way, if not the only true way, of truth and life. Though cultured, they do not despise religion. They are often 
gentle, moral, spiritual appreciators of religion — often even of religions other than their own. Unlike Schleiermacher who directed his lectures toward religion's cultured despisers, I am directing my essay, not to the adherents of alternative religions: Hindus, Buddhists, Jews, and Muslims, but to their Christian neighbors. For, after all, pluralism presents an opportunity $-\mathrm{a}$ religious marketplace - for bearing witness to our Lord Jesus.

Terry C. Muck, Professor of Religious Studies and Christian Mission at Asbury Theological Seminary is an expert on alternative religions in America. In his useful book Those Other Religions in Your Neighborhood: Loving Your Neighbor When You Don't Know How (1992), Muck estimates that ten percent of the 175 million adults in the United States "claim a non-Christian religion as their own" (1992:17). We have all seen the construction of non-Christian worship space in our neighborhoods: Hindu and Buddhist temples and Islamic mosques add their profiles to the Jewish synagogues already on the skyline of American cities and villages.

On the university campuses of America Asian-American students represent a presence much larger than the percentage of the population they comprise. Muck shows that, while they represent $2.8 \%$ of the population, Asian-Americans make up 12\% of Harvard University's student body. At Stanford the number is $20 \%$ and at U. Cal. Berkeley, 30\% (1992:17). Not all practice Hinduism, Buddhism, or Islam, but a good percentage of them come from such backgrounds. They come to reside in our neighborhoods - their neighborhoods - as teachers, doctors, lawyers, engineers, entrepreneurs, and sales people. Some students have elected to take my seminary courses on Hinduism, Buddhism, Islam, and Judaism only because members of their own immediate or extended families were adherents of one of these global, resurgent religions. 
Whether as students or householders, many of these cultured adherents of other religions surface as devout representatives of their faiths. Because our neighbors are cultured but not despisers of religion, the cultural pluralism they represent affords an opportunity for good neighbors and Christian witnesses. For the same reason the opportunity overwhelms us.

In my first year of preparation for what I anticipated would be a lifetime of Christian witness to Muslims, I joined a group at the University of Maryland headed up by a chemistry professor from Taiwan. This group of Christians would meet at her house once a month to entertain international students and get to know them. In this setting I met my Muslim friend, Qais Sharbati. I easily interested Qais in coming with me to the little church where I was youth pastor on a Sunday when I was to preach. After the service ended, while I was greeting everyone as they filed out the door, Qais mixed cheerfully with the friendly people who had survived my sermon. Before I finished with my after church duties, Qais had made his way back to the car. When I arrived, I found him in his seat crying. An exchange something like this followed: "Qais, what are you feeling?" (I of course thought he was responding to my message directed unobtrusively his way)

"It is so wonderful," he said through his tears, "to be among people who love God." He went on to explain, wiping his eyes, "I left Iraq hoping to meet Christians and find out more about them. This is the first time I have been among a group of Christians or among any people who love God." At this time, he may not have realized our little group at Maryland University was a Christian group.

Frankly this experience shocked me. I later realized I had been thinking of people of other faiths as empty people ready to be moved by the message of the gospel in order to be filled with happiness and meaning. Here was a lover of God searching in a rather secular setting for 
others who loved God. He had found what he was looking for in my church - not through the message, but through the people. And to be further honest, I didn't really "get it" until many years later. At that time and for many years afterwards I trusted the message. Due to trust in the message, I had taken him to church on a day when I was preaching because I was not sure the pastor would get it right for Qais. I was 23 years old at the time.

Now nearly forty years later, what have I learned? Let me offer you some guidelines for witnessing to Christ among such devout and cultured believers in alternate faiths as Qais. What I have to say can be expressed in four mottos. These mottos say in essence, build relationships, keep persons in the foreground, let God work within them, and overcome fear and false witness within yourself.

\section{Building relationships is more important than tearing down strongholds}

My experience with Qais should have clued me into the importance of relationships. Instead it confused me. I was unprepared for such a devout and transparently sincere lover of God who was a Muslim. I have since that time met a number of such people. It is hard to tell them they are sinners and need a savior. The conversation just doesn't come around to that. Furthermore it does not work. The important thing is to build a relationship and trust God to work in the situation. Do not be impatient. Allow God to work.

If I had known this back in 1961, I would have pursued my relationship with Qais more diligently and waited for God to open a chance to talk in deep love to this cultured, educated, and devout Muslim. I do not mean to suggest that "tearing down strongholds" is unimportant. Fervent prayer that God will free your friend to understand and respond to God the Father of our Lord Jesus Christ represents a crucial part of the picture. It is best to think of our friend, 
however, not as territory to be taken, but as an on-going divine project - a person in whom God has been at work since birth and probably even before birth.

A missionary I have heard about, after preparing himself well to serve the Lord in an Islamic country, found he could not enter it. Managing to get a job teaching at a Middle Eastern University, he enlisted the aid of some students there from the country of his call to help him learn their language. He eventually had them help him translate the Gospel of Luke and other portions of the Bible and record them on tape in their heart language. In the process of the lengthy relationship entailed in these projects, two of these young men came to faith in Jesus as Lord and Savior. Some of the people he used to help him with the language and his translation planted churches in several villages of their country using these Bible tapes. A whole sect of Islam in that country has gotten permission from their spiritual leader to listen to these tapes. His informants were eager to help him because he alone showed an interest in their language. He built relationships through an interest in them and their culture.

Building relationships with neighbors of alternate faiths may entail cooperating with them on civic issues that involve morality. In connection with one of my class trips to the Muslim Community Center in Irving Park Chicago, a Muslim parent made an impassioned plea for us as Christian leaders to cooperate with other religions in bringing back morality to the public schools. He told of talking to the principal of his son's school about the importance of teaching the children not to steal. I guess his son had had something important stolen.

The principal insisted his school could not teach values because of the separation of church and state.

Most alternatives to Christian faith have major areas of common ground with us in moral values. We can cooperate with others in civic and educational matters to build a better society. 
We can protect the freedom of religion together while building a strong moral base for our society. This brings us together with people of other faiths and provides a ground for sharing the reasons for the hope that lies within us.

Terry Muck, in the work referred to earlier, proposes creating a forum for such cooperation. The forum would serve as a court for conflict resolution where complaints of religious groups could be aired. It would convey concerns of religious groups to the governing authorities, receive communications from the governing authorities relating to religion such as tax exempt and non-profit status, and provide a platform for religious groups to address the world on issues such as religious freedom (1992:163-64).

A problem with building relationships emerges in just about everybody's mind, however, when we contemplate relating closely with devout, knowledgeable Muslims, Hindus, Buddhists, and Jews. How do I know enough about them to work with them effectively, to say nothing of leading them to Christ? My second motto addresses this problem.

\section{You can never know enough, but you can easily know too much.}

Think again of my Qais Sharbati. I thought of him as a Muslim and not a lover of God - or a person who thirsted to be with lovers of God. I came to this conclusion by making foreground what should have remained background.

What I know about a person's religion and what I know about the gospel and how to communicate and defend it should always be background. Qais, the person, should have been foreground. Lack of background knowledge can be an advantage if because of it you have to learn a lot about the person you are relating to. The more background knowledge you have the better-if it remains background. The person must be your focus of attention. 
Once I tried to share the gospel with an Iranian graduate student at the University of Kentucky. Seeing him sitting alone at a table in the student center food court, I got myself a cup of coffee and a donut and made my way over to his table. When I asked if I might sit down and talk with him about faith in God, he readily consented. It turned out he was a graduate student in engineering. I began to share with him my interest in the Qur'an and Islam.

Being a little nervous about such conversations anyway, I went on and on about my interest in his religion. It was also a way I thought of identifying with him. In the midst of all this, it was almost as though a voice said to me, "Where is the Holy Spirit at work in his life?" I immediately stopped and asked him, "By the way, how are things going with you?" "Really bad," he said. "I am very dissatisfied with my program but I can't change universities because my wife has been very sick and unable to move. I am really discouraged." Counseling with him along these lines occupied us for a while. We were really warming up to each other when he said, "By the way, I know almost nothing about Islam, even though it is supposedly my religion. You appeared to know so much I was embarrassed to talk to you."

"Would you like to know more about Islam?” I asked him. "Yes," he said, "I would.” I told him I had a catalogue of tapes on Islam published by a Muslim publishing company in Texas I would be glad to send him. He seemed eager to get the catalogue. Then I said, "I would also like to send you a copy of the New Testament in Persian. Would you be interested?" Again he seemed eager for that too. So I sent him both. I also notified a Christian family in his apartment building about his and his wife's need for support and companionship.

With a doctorate in Islamic studies and an intense interest in the Qur'an, I knew too much. Initially, background won out over foreground. If you get to know the persons from other religions and cultures in your neighborhood, you may discern where the Holy Spirit is at work in 
their lives. Then your background knowledge will be very helpful. When background becomes foreground, however, it is better to have as little as possible.

I find background knowledge can often be brought into a relationship through a genuine question. I asked one of my closest Muslim friends while he was spending a week with me in my home a question about what the Qur'an says about the Bible. I said, "It seems to me that the Qur'an never really says anything negative about the scriptures of the Jews and Christians. It only criticizes them for the way they were using it deceitfully. Is this true or not?” This man knows much more of the Qur'an than I do, so it was a genuine question. Well, he did not know the answer to that one. But the next year, when he was speaking at an interfaith dialogue I participated in, he made this statement: "I have been reading the Qur'an itself without reference to later commentaries. I find it says nothing negative about Jewish and Christian scriptures as such.” This represented an important step toward encouraging Muslims to read our Bible. Background knowledge can be helpful, but it is not essential. What God is doing in the life of the person with whom we are building a relationship is the key issue-the person is foreground.

A third motto also relates to the meeting I had with the Iranian engineer. 


\section{It is better to inspire hope than to be admired.}

I so impressed the Engineer with my knowledge of things Islamic and Qur'anic that he was embarrassed at how little he knew. When we got into his very difficult and discouraging situation, however, hope began to emerge. He caught a glimpse of light at the end of his tunnel and I managed to find a way to get him a copy of the New Testament and to connect him with a Christian family.

When we build relationships with people of other faiths, we try neither to impress them with our piety nor to win a Christianity-is-a-more-clever-way-of-believing-than-Islam-orBuddhism contest. Instead, we offer the Holy Spirit a bigger arena for inspiring the hope that God can in fact be known, that their sins can be forgiven, and that they can be enabled to live the kind of life their faith offers as an ideal.

Nantachai Mejudhon was peacefully studying engineering at a California university when his world caved in. He received a letter from Ubolwan, his fiancée, declaring she had accepted Christ and that, if he wanted to marry her, he would have to accept Christ too. The letter shattered the world of this devout Thai Buddhist. His fiancée had been a teacher of Buddhist philosophy on the same campus in Thailand where he taught engineering. They had planned to marry and devote themselves to promoting the Buddhist dharma. Now what was he to do?

He was so determined to marry his beloved that, while he tried to persuade her to change her mind in letter after letter, he feverishly read the Bible all the way through and attended churches, hoping to succeed in becoming a Christian. Nothing seemed to work for him. He could not come up with any real experience of God. At long last, a series of unusual events unfolded that broke the logjam in his heart. 
One event proved very embarrassing and discouraging. He enrolled in a Campus Crusade Bible study as part of his unsuccessful effort to become a Christian. One night the teacher showed up late and very drunk. Nantachai, greatly discouraged by this turn of events, said to himself, "We Buddhists are better than this Christian. At least we can discipline ourselves to avoid drunkenness."

The next day he met his teacher in the library. The teacher, apologizing sincerely for his behavior, asked Nantachai's forgiveness. Nantachai was so impressed by the teacher's confession that the event ended up helping him experience the glorious melting of his heart that assured him of his acceptance by God. Hope for his forgiveness emerged out of the ashes of his teacher's lapse of discipleship. The Bible study leader probably thought his days of admiration by his students had ended. Clearly drunkenness offers a poor Bible teaching strategy, but God used even it to inspire hope in Nantachai.

Because building relationships is not easy, knowing people takes time, and potential humiliation threatens self-esteem, we need my fourth motto. 


\section{Overcome yourself not the enemy.}

Two main obstacles within ourselves need to be overcome if we want to reach the cultured believers in alternative religions: fear and falsehood.

Fear. The greatest obstacle within ourselves is fear. I used to go to the University of Kentucky to reach out to people in the student center as I described above in connection with the Iranian student. I felt nauseous with fear on Sunday night anticipating the next day's interactions. Building relationships with friends will help overcome this fear. I included a field trip to synagogues, mosques, and temples in my classes on world religions partly because contact with people helps overcome this fear. Building relationships will help more than anything else to remove fear. Here we can appropriately say, "Just do it." I think fear is the biggest barrier. But falsehoods also abound, hindering witness.

Falsehoods. Some falsehoods we may have internalized can hinder our building the kind of relationships that lead to good opportunities for witness. One is the often repeated-but seldom examined-cliché, happiness can only be found in Christ. I have heard public speakers glibly chirp this out. The result is that people who have internalized this erroneous generalization avoid contact with people who are happy outside of Christ. Avoidance of contact with the cultured among the alternatives to Christian faith will not get us anywhere with the cause of Christ. Yes, only Christ offers the kind of happiness he defines in the Beatitudes. But I do not think that is what the easy speakers mean. Furthermore, some people have been led to believe all people from all times and places who have not explicitly trusted in the Jesus of the New Testament as their personal savior will spend eternity in Hell.

While this conviction matches certain texts of Scripture taken in isolation, it conflicts with what Jesus teaches about God. It hinders witness in the same way the 
happiness-only-in-Christ cliché does. We subconsciously or consciously withdraw from situations threatening the structure of our worldview. We will not covet companionship with saints in other religions who seem to deny the truth of this conviction.

A final general false witness equates all supernatural activity among people of other religious traditions with the work of the Devil. The gods they worship, the ancestors who appear to them, the healings taking place among them, and the dreams revealing future events to them are not necessarily demonic. God may be at work in them-or some other powers not necessarily evil.

The God and Father of our Lord Jesus Christ - the God of the Bible - works among all people. Not all the good things that happen to them come from the Evil One. Just as the Devil appears in the pages of Holy Writ, so the Devil plays a role in the lives of people of other faiths and has played a role in the development of their traditions. But that does not a statement suchas the following appearing in a leading missionary periodical. It considered Hindu India "the most perverted, most monstrous, most implacable, demon-invaded part of this planet. There's just no question about it. The greatest, biggest, blackest, most hopeless mass of confusion, perversion, deception, and oppression is this massive Hindu bloc" (Winter 1994:17).

Pluralism in America and many other parts of the world presents a marvelous opportunity for building relationships with people of other faiths. I encourage you to build those relationships, to focus on persons, to inspire in them the hope that they can know God, find forgiveness, and live more devoutly in Christ. I am convinced we can overcome our fear and our falsehoods that stand in the way of God's work in their lives. 
One of my current students is building a relationship with a devout Muslim. After several lengthy discussions with him, my student has come to respect his sincerity, devotion, and convictions profoundly. He asked me as we met to discuss his relationship, "Is there any chance that this man will come to Christ?" Without hesitation I said, "Yes." Quite possibly he will come to Christ. We do not know what God will bring into his life that will turn his attention in a totally new direction. I told my student about a friend of mine who went from being an atheist to having a profound faith in God as a result of participating in the Muslim religion. Down the line, however, he became very upset with the leaders of his movement and after a trip down into the Hell of cocaine, he was resurrected through crying out to God in a Christian church. He is now the director of men's ministry at a Christian rescue mission.

In Phillip Roth's masterful short story "The Conversion of the Jews," a precocious Jewish boy named Oscar Friedman gets in big trouble in his Bar Mitzvah class because he is convinced that God could cause Jesus to be born of a virgin — something his spiritual leader, Rabbi Binder, denies. Rabbi gets so upset with him over this insistence that he makes him sit by himself and think it over. After a long time of thought, including rehearsing the amazing fact that the Bible says God created light, he declares, "I'm convinced God could do it" (1969:102). This is my conviction about the cultured among believers in alternative religions in a world of pluralism. God can bring them to Christ through us. I'm convinced God can do it.

\section{References Cited}

Lo, Jim \& Johnson, Boyd

2006 Intercultural Ministry: Readings on a Global Task. Precedent Press. Muck, Terry C. 
1992 Those Other Religions in Your Neighborhood: Loving Your Neighbor When You Don’t Know How. Grand Rapids, MI: Zondervan.

Roth, Phillip

1969 "The Conversion of the Jews.” In Good-bye, Columbus and Five Short Stories. $2^{\text {nd }}$ ed. New York: Bantam, pp. 101-14.

Schleiermacher, Friedrich

1988 On Religion: Speeches to its Cultured Despisers. Intro., trans., and notes Richard Crouter. Texts in German Philosophy. Ed. Raymond Geuss. Cambridge, New York, New Rochelle, Melbourne, Sydney: Cambridge University Press. The German original first published in 1799 was called Reden über die Religion.

Winter, Ralph

1994 “The Daunting Task of Hindusim.” Mission Frontiers 16(1):11-12. 